\title{
"Yan, Of, Ef, Viç, İç, İs, Dis, Pulos ...": the Surname Reform, the "Non-Muslims," and the Politics of Uncertainty in Post-genocidal Turkey
}

\author{
Emmanuel Szurek
}

On 29 November 1934, this unsigned editorial appeared in the Istanbul-based newspaper Cumhuriyet:

Compatriot, it's your turn!

Mr. Baruh, secretary of the B'nai B'rith Jewish gymnasium, has stated that he has adopted the word Batu, meaning "strong," as his surname, and that in so doing his purpose is to incite the Jews to adopt pure Turkish surnames.

Last year there were Jewish children who took Turkish first names. ${ }^{1}$ Just like the Turks, the Jews of Turkey do not have surnames. Names such as Behar, Nesim, Levi and Kohen do exist just like ours, and many people make use of them, but these people do not come from the same lineage. From now on, by choosing pure Turkish surnames, they will have made a step toward Turkification.

The Armenians and the Rums do have surnames. All Armenian names end in yan, but among the Rums there are numerous surnames ending in oğlu, which is Turkish. "Baklacıoğlu," for instance ... But there are also many Rums whose surname is not Turkish.

Just as the Surname Law states that names of foreign races and nations cannot be used as last names, it is likewise written in the Surname Regulation which is in preparation at the Council of State that suffixes and words expressing the idea of another nationality and taken from

1 On this episode, see Rıfat Bali, Cumhuriyet Yıllarında Türkiye Yahudileri. Bir Türkleştirme Serüveni (1923-1945) (Istanbul: İletişim, 1999), 287, and Meltem Türköz, Naming and Nation-Building in Turkey. The 1934 Surname Law (New York: Palgrave Macmillan, 2018), 65-7. 
other languages (such as yan, of, ef, viç, iç, is, dis, aki, zade, mahdum, bin) shall not be attachable to the new surnames, and that it will no longer be possible to use those previously attached.

This Regulation has not been issued yet, but it will be soon. As of now, just as a Turkish Jew will no longer be able to use the word Levi as a surname, a Turkish Armenian can no longer use a surname ending in yan, and the Rums of Turkey, too, will have to change those of their surnames which do not end in oğlu.

In these times when all Turks are striving to take a surname, Greek, Armenian and Jewish compatriots would also do well to show a little enthusiasm in taking pure Turkish names. In so doing, they would show how glad they are that the laws of the Republic do not set them apart and that they are not treated differently from the Turkish citizens. ${ }^{2}$

A widely discussed question with regard to the dialectics of Islam, race, and secularism in post-Ottoman Turkey, is "Who is a Turk?" The perspectives of legal and social practices of state and non-state actors have led scholars to various answers, ranging, ideal-typically, from the duplication of the civic selfnarrative of the Republic (all nationals of Turkey are Turks) to more or less exclusive interpretations based on language, religion and ethnicity (true Turks are the sole Turkish-speaking Sunnis of the country, but Muslim refugees and migrants, together with the autochthonous Alevis, Kurds, Arabs, and Laz, are eligible Turks). ${ }^{3}$ On paper, the non-Muslims were full-fledged citizens, and as such, they, too, were subject to policies of forcible assimilation or Turkification. ${ }^{4}$

2 Cumhuriyet, 29 November 1934. Unsigned editorial.

3 Ahmet Ylldız, "Ne Mutlu Türküm Diyebilene." Türk Ulusal Kimliğinin Etno-Seküler Sinırları (1919-1938) (Istanbul: İletişim, 2001); Nazan Maksudyan, "The Turkish review of anthropology and the racist face of Turkish Nationalism," Cultural Dynamics 17,3 (2005): 291-322; Howard Eissenstat, "Metaphors of Race and Discourse of Nation: Racial Theory and the Beginnings of Nationalism in the Turkish Republic," Paul Spickard (ed.), Race and Nation: Ethnic Systems in the Modern World (New York: Routledge, 2005), 239-56; Soner Cağaptay, Islam, Secularism, and Nationalism in Modern Turkey. Who is a Turk? (New York: Routledge, 2006); Derya Bayır, Minorities and Nationalism in Turkish Law (New York: Routledge, 2016/2013); Lerna Ekmekçioğlu, "Republic of Paradox: The League of Nations Minority Protection Regime and the New Turkey's Step-Citizens," International Journal of Middle East Studies 46,4 (2014): 65779; Gregory J. Goalwin, "Understanding the exclusionary politics of early Turkish nationalism: an ethnic boundary-making approach," Nationalities Papers 45,6 (2017): 1150-66.

4 Ayhan Aktar, "Cumhuriyetin ilk yıllarında uygulanan 'Türkleştirme' politikaları," Tarih ve Toplum 156 (1996): 4-18, Bali, Cumhuriyet Yillarında. 
A much-cited example is the "Citizen, Speak Turkish!" mobilization, a campaign of intimidation launched in 1928 by university students, teachers, and journalists in order to force the non-Turkophones, particularly the Ladino- and French-speaking Jews and the Greek-speaking Rums of Istanbul and Izmir, to abandon their mother-tongues. ${ }^{5}$ In the meantime, however, the non-Muslims were also exposed to various policies and practices of marginalization in public life and the job market, discrimination in private business, limitation of movement, forced displacements, denationalization, and spoliation - all matters which led them not only to be "lesser Turks" in Turkey but also to leave Turkey. ${ }^{6}$ This phenomenon has been referred to as minoritization, ${ }^{7}$ a concept increasingly popular within the broader field of post-Ottoman and Middle-Eastern studies. $^{8}$

Dated 29 November 1934, the editorial cited above could be a textbook illustration of this paradoxical Turkification-vs.-minoritization process. Its author was, I presume, Yunus Nadi [Abalığlu ${ }^{9}$ ], a leading figure of Republican Turkey, once close to Talât Pacha, now a friend of Mustafa Kemal and the chief editor of the Cumhuriyet. This daily newspaper was known to be the semiofficial voice of Ankara in Istanbul, the former capital of the Ottoman Empire and still a multi-confessional city. Right from the onset, the former Young Turk addressed the non-Muslims inclusively: "Compatriot, it's your turn!". This title was probably an echo of the "Citizen, Speak Turkish!". campaign, which

5 Senem Aslan, “'Citizen, Speak Turkish!': A Nation in the Making," Nationalism and Ethnic Politics 13,2 (2007): 245-72.

6 Talin Suciyan, The Armenians in Modern Turkey. Post-Genocide Society, Politics and History (London: I.B. Tauris, 2016).

7 Zeynep Kezer, Building Modern Turkey. State, Space, and Ideology in the Early Republic (Pittsburgh: University of Pittsburgh Press, 2015), 119.

8 Jane K. Cowan, "Ambiguities of an Emancipatory Discourse: the Making of a Macedonian Minority in Greece," in Jane K. Cowan, Marie-Bénédicte Dembour and Richard A. Wilson (eds.), Culture and Rights. Anthropological Perspectives (Cambridge: Cambridge University Press, 2001), 152-76; Mahiye Seçil Dağtaş, "Heterogeneous Encounters: Tolerance, Secularism and Religious Difference in Turkey's Border with Syria” (Unpublished PhD, University of Toronto, 2014); Nathalie Clayer, "The Muslims in South-Eastern Europe. From Ottoman Subject to European Citizens," in Roberto Tottoli (ed.), Routledge Handbook of Islam in the West (New York: Routledge, 2015, 70-84); Laura Robson (ed.), Minorities and the Modern Arab World. New Perspectives (New York: Syracuse University Press, 2016); Güldem Baykal Büyüksaraç and Jonathan Glasser, "Inhabiting the Margins: Middle Eastern Minorities Revisited," Anthropological Quarterly 90,1 (2017): 5-16; Güldem Baykal Büyüksaraç, "Trans-border Minority Activism and Kin-state Politics: The Case of Iraqi Turkmen and Turkish Interventionism," Anthropological Quarterly 90,1 (2017): 17-54.

9 Surnames customarily appear between brackets when related to a period prior to the passing of the Surname Law. 
was still in effect in $1934 .{ }^{10}$ Still, the author consistently 'otherized' the nonMuslims by contrasting them with 'the Turks,' or by letting an implicit 'us' loom in such phrases as "our names," as opposed to theirs. The last sentence is particularly telling. First, it was for the non-Muslims to prove their eagerness to be part of the nation by adopting 'pure-Turkish' names (something which would soon be requested from them by law anyhow - or so the journalist thought). In other words, anticipating rather than just obeying the law was in order. Second, in a striking lapsus calami, the journalist invited his "Rum, Armenian and Jewish compatriots" to show their willingness not to be treated differently "from the Turkish compatriots," not the other Turkish compatriots - finally casting doubt on whether he did view the non-Muslims as his fellow citizens, after all.

In sum, this editorial encapsulated the tension between the desire to see the non-Muslims quickly incorporated by onomastic assimilation - and thus made less visible - , and the pervasive inclination to keep them at bay - and in sight - by discursive dissimilation. Both insiders and outsiders, Turkey's non-Muslims were caught in the double bind of a self-proclaimed secularist integration and an enduring sense of differentiation based on religion. ${ }^{11}$ The persistence of the Turkish state in reiterating ambiguities of this kind, or its consistent inconsistency within the realm of the law, I call the 'politics of uncertainty.' In this chapter, I wish to investigate this phenomenon through the case of the Surname reform, a policy still wrapped in much obfuscation with regard to the non-Muslims.

Launched in June 1934, the reform was to be theoretically implemented from January 1935 to July 1936. In terms of linguistics, it constrained the naming practices of citizens in three ways. Formally, it made it compulsory for every Turk to have a set of two official identifiers (first name + surname). Semantically, some surnames, because of their meaning in Turkish, were deemed anti-national or disgraceful, and therefore prohibited. Etymologically, newly adopted surnames had to be selected from Turkish. This last provision was undoubtedly enforced for Muslim citizens ( $98 \%$ of the population), the vast majority of whom lacked

10 Alexandros Lamprou, "Nationalist Mobilization and State-Society Relations: The People's Houses' Campaign for Turkish in Izmir, June-July 1934," Middle Eastern Studies 49,5 (2013): 824-839.

11 Marc Baer, "The Double Bind of Race and Religion: The Conversion of the Dönme to Turkish Secular Nationalism," Society for Comparative Study of Society and History 46,4 (2004): 682-709; Ekmekçioğlu, "Republic of Paradox"; Bayır, Minorities and Nationalism. 
a standardized patronymic name. ${ }^{12}$ Individuals with names sounding Kurdish, Arab, Slavic or Circassian were not authorized to turn those into their official surnames. The question is whether those who already had a patronymic - as was critically the case for most Armenians, Rums and Jews - had to abandon it or not. ${ }^{13}$ Of all citizens, it was they whose naming practices came closest to the new patronymic order, due to both their own onomastic practices and longue-durée entanglement with Europe, where surnames had been in order for centuries. ${ }^{14}$

Should the non-Muslims be forced to adopt a Turkish-sounding surname or not? Option 1 (Turkification) meant forcing them to abandon their anthroponymic heritage (just like the non-Turkish Muslims) but fully incorporating them into the national community, as embodied by an etymologically homogenized onomasticon. Option 2 (minoritization) meant keeping the patrimony safe but leaving the owners clearly visible, to the authorities if not in everyday life, as "the non-Muslims." ${ }^{15}$ In times of continued persecution, both statedriven and at street level, ${ }^{16}$ this was probably not the best option for the nonMuslims, many of whom eventually opted for Turkish surnames (individually). But from the perspective of a state that in many respects had taken up the Young-Turk duty of homogenizing the country on an ethno-confessional basis,

12 On the prevalent, yet contested, conception that Turks/Ottomans did not have family names, see Olivier Bouquet, Les noblesses du nom. Essai d'anthroponymie ottoman (Turnhout: Brepols, 2013), 145-187; Emmanuel Szurek, "To Call a Turk a Turk: Patronymic Nationalism in Turkey in the 1930s," Revue d'histoire moderne et contemporaine [Online] 60,2 (2013); Türköz, Naming and Nation-Building, 39-41 and 71-74.

13 There were many exceptions to this divide. Muslim refugees from the Balkans, former Persian subjects (where surnames had been adopted in 1925) could have a standardized surname prior 1934, while many non-Muslims of (Eastern) Anatolia lacked one or had a Turkish-sounding surname. See Houchang Chehabi, "The reform of Iranian nomenclature and titulature in the fifth Majles," in Wali Ahmadi (ed.), Converging Zones: Persian Literary Tradition and the Writing of History: Studies in Honor of Amin Banami (Costa Mesa: Mazda Publishers, 2012), 84-116; Bouquet, Les noblesses du nom, 117-143.

14 Ilsen About and Vincent Denis, Histoire de l'identification des personnes (Paris: La Découverte, 2010).

15 After Lausanne, the Armenians, Rums and Jews were the only non-Muslim 'minorities' recognized as such by Ankara. They should not be too casually equated with the nonMuslims. See Baskın Oran, Türkiye'de Azınlıklar: Kavramlar, Teori, Lozan, İç Mevzuat, İçtihat, Uygulama (Istanbul: İletişim Yayınları, 2005/2004), 67-80.

16 For instance, the so-called "Thrace events" - a pogrom which led over 15,00o Jews to leave their homeland in Eastern Thrace - started as the Surname Law was under discussion in Ankara. See for instance Rufat Bali, 1934 Trakya Olayları (Istanbul: Kitabevi, 2008). 
option 2 could be deemed a preferable course of action. ${ }^{17}$ The vast majority of those who have touched upon this question, as we shall see, have argued that assimilation prevailed: the non-Muslims, they hold, were legally compelled to Turkify their surname. I hope to show that this is inaccurate: if anything, the reform ended up legally differentialist - for the non-Muslims - , rather than assimilationist (which it was for the Muslims), for reasons that require both a national and a transnational frame of analysis.

More importantly, by a close reading of the multiple injunctions that punctuated the Surname reform - the law itself (June 1934); its regulation (December 1934); the Interior Ministry's rulings (January 1935) and instructions (April 1935) - , and with particular attention to the timing of those prescriptions, I hope to demonstrate that with respect to the non-Muslims the reforming process was impregnated with ambiguity from beginning to end. Whether intentional or not, such inconsistency led the authorities to a series of legal flip-flops - back and forth between assimilation and differentiation. Thus, research on the surname reform, I argue, has failed to fully grasp this normative zigzagging and the kind of majority-'minority' relationship it was likely to reveal, twenty years or so after the disappearance, by death or deportation, of 2.5 million Ottoman Christians.

My perspective in this chapter is elite- and state-centred, and focuses on the making of the legal apparatus of the reform rather than on its implementation. Examining more documents from the non-Muslims and their institutions and taking the point of view of private individuals, through oral history, would certainly lead to a more complex picture in terms of onomastic agency and creativity. ${ }^{18}$ Still, I maintain that when it came to the non-Muslims the volatility of the state remains to be factually documented. To that end, I have used mainly Turkish sources: records of the proceedings of Parliament, the multilayered normative documentation of the reform, national newspapers, and administrative documents. Since the issue also has a transnational dimension, I have also used Istanbul-based French and Rum newspapers, along with a few

17 In Turkey, the surname has remained an identifier that is less used, in everyday life, than the first name, which can also be a marker of ethno-confessional belonging. And so, the fact that first names were kept outside the reform does constitute a limitation to the discriminatory potential of the new surnames. But this nuance, in turn, calls for qualification: names are not only tools for identification, they also carry a symbolic repository, and "tell a story"; as such, they have practical effects on individuals' life. See Nicole Lapierre, Changer de nom (Paris: Stock, 1995).

18 By conducting interviews in the late 1990s, Meltem Türköz was for instance able to explore the registers of meaning through which individuals make sense of their own memories of the reform. Originally a $\mathrm{PhD}$ in social anthropology (2004), her excellent Naming and Nation-Building is the most thorough study of the surname reform. 
American and French diplomatic archives. It should be clear at this point that the archives of the Turkish Interior and Foreign Affairs Ministries unfortunately remain closed. ${ }^{19}$

\section{Denotation, Not Connotation. What Law 2525 Was Mainly About (June 1934)}

Before 1934, a Muslim Ottoman was likely to have a variety of names. First came the Islamic isim (Ali, İbrahim, Zeyneb). When more complex sociability requested further differentiation, one could resort to a mahlas (nickname, pen name), which was conferred to an individual early in life by a superior according to such considerations as morals, educational performance, tour d'esprit, etc. Finally, most elite people had a lakab, i.e., an additional mahlas, but reflecting reputation rather than being a single designator. The lakab indicated one's geographical origin, family background, outstanding achievements etc. However, none of these identifiers were fixed. On the contrary, switching names and categories of names happened frequently in a lifetime. Thus, most Turks did not bear standardized family names, although there did exist kinship groups with transmissible names of family. ${ }^{20}$ A classical state-building policy, ${ }^{21}$ the surname reform thus represented both an effort in formal homogenization and onomastic stabilization: unlike the Ottoman subjects, the Turks would all use the same categories of names (first name + surname), and would theoretically use the same identifiers throughout their lifetime.

A follow-up of the adoption, or adaptation, of the Swiss Civil Code (1926), in which the family name was mentioned several times, ${ }^{22}$ the reform was launched in 1929, then stopped, then revived. A bill was finally submitted to Parliament in March 1933. The man in charge was the Interior Minister Şükrü Kaya (1927-1938). On 16 June 1934, he explained to the deputies in what perspective the bill had been drawn up:

19 I am greatly indebted to Antonis Nasis for translating sources in Greek, and to Illker Aytürk and Erik-Jan Zürcher for their insightful remarks. My thanks also go to Güneş Işiksel, Nicole Lapierre, Cilia Martin, Işık Tamdoğan, Duygu Taşalp, and Claire Zalc.

Robert F. Spencer, "The Social Context of Modern Turkish Names," Southwestern Journal of Anthropology 17,3 (1961): 205-218; Olivier Bouquet, "Onomasticon Ottomanicum: identification administrative et désignation sociale dans l'État ottoman du XIX ${ }^{\mathrm{e}}$ siècle," Revue des mondes musulmans et de la Méditerranée 127 (2010): 213-35.

21 Gérard Noiriel (ed.), L'identification. Genèse d'un travail d'État (Paris: Belin, 2007). 
Of course it is your high assembly that will be sovereign. Just allow me to add this: this is a law of modernization. This is a law that your servant and other friends at the Ministry have worked on with all their power. [...] How was [similar legislation] elaborated in France? What kind of law did Napoleon produce? What was done by François I? How did the Germans give names to the Jews? They asked the French how they would attribute family names no matter what happened to the Algerians. ${ }^{23}$

The minister did not say what purpose - etymological or just formal - was served by the comparison with the German Jews or the Algerian indigènes, ${ }^{24}$ nor which groups were considered their equivalents in Turkey, if any. But his words did illustrate the Eurocentric civilizationism of the reformers, and their ambition to build a nation through names. And yet, it seems that when debating the law the deputies were not much preoccupied with the non-Muslims and the etymological challenge raised by their surnames. After all, dealing with the $2 \%$ who already had surnames when $98 \%$ of the 16 million citizens did not, was no priority. Moreover, the law had been placed on the agenda just before the end of the parliamentary session (6 July), so that the draft was discussed quickly, among other bills, on 16,18 , and 21 June, with a fervour that did not pass the French observers unnoticed: "From May onward, the zeal of the Grand National Assembly was observed, whose careful control extends to all objects, and which has passed a considerable number of legislative proposals [...]."25 Thus, we may simply conclude that the minorities were outside the deputies' scope when the Surname law, or Law 2525, was finally passed.

However, other elements suggest that the omission of the non-Muslims may have been intentional. The draft originally submitted to the Assembly (March 1933) did indeed state that "All Turks have a name taken from the Turkish language" (Article 3). Yet, this obligation was omitted from the version revised by the Committee of Internal Affairs (December 1933), as well as from that corrected by the Justice Committee (May 1934). ${ }^{26}$ Moreover, in March 1934, another bill on surnames had been submitted: in the explanatory statement, its promoter, the deputy of Muğla Nuri Bey, recommended that future surnames be devoid of any "influence of religion or racial belonging"

23 Türkiye Büyük Millet Meclisi Zabıt Ceridesi (hereafter TвMMZc) IV, 23, 69, 198.

24 The imposition of a patronymic system in colonized Algeria still awaits its historian. See Farid Benramdane, "Qui es-tu? J'ai été dit. De la destruction de la filiation dans l'état civil d'Algérie ou éléments d'un onomacide sémantique," Insaniyat 10 (2000): 79-87.

25 Bulletin périodique de la presse turque 102, 2 (1934).

$26 \quad T B M M Z c$ IV, 23, annex. 
(dinin ve rrkî milliyetinin tesiri). Thus, he had an article drawn up stipulating that "Surnames are made of one or two Pure-Turkish words making a single composed word with the suffix -gil."27 Nuri's bill did not make it to the vote, but its contents confirm that the Turkification of all names was not excluded when Law 2525 was finally adopted. ${ }^{28}$ I here quote Article 3 in its final version:

The use of civil and military ranks and titles as surnames, as well as the names [isim] of tribes [aşiret] or of foreign races [ $[\mathrm{rk}]$ and nations [millet] is forbidden, and so are the names that are not suited to public morals, or else names that are disgusting or ridiculous. ${ }^{29}$

The sense and purpose of Article 3 were clarified by Şükrü Kaya in the Chamber (21 June):

Then we want to suppress the names of foreign nationalities. In our country, certain people who came from abroad and became natives of the country [memleketimiz yerlisi] bear names of other communities [başka bir camia]. For instance, there are thousands of names like Arap [Arab], Çerkes [Circassian] or Çeçen [Chechen].

It is necessary to suppress those names. For instance, those who use such names as Ibrahim-the-Chechen [Çeçen İbrahim] or Mehmet-the-Laz [Laz Memet (sic)] must definitely find other names for themselves. This is why our purpose is to suppress the separation that does not actually exist in reality but still lives in people's minds. ${ }^{30}$

Article 3 continued the Government's efforts to homogenize the country by destroying all affiliations that were deemed non-national. ${ }^{31}$ Still, it did not forbid

$27 \quad T B M M Z C$ IV, 23, 71, 191.

28 For another example of such etymological concern, see the words of Ziya Gevher Bey, deputy of Çanakkale, who proposed a motion that "the name cannot be from any foreign language" (quoted in Türköz, Naming and Nation-Building, 71).

29 T.C. Resmi Gazete 2741, 2 July 1934.

$30 \quad$ TвMMZC, IV, 23, 71, 246.

31 Such was particularly the purpose of the Settlement Law, adopted five days before Law 2525. See Türköz, Naming and Nation-Building, 73, and Erol Ülker, "Assimilation, Security and Geographical Nationalization in Interwar Turkey: The Settlement Law of 1934," European Journal of Turkish Studies [Online], 7 (2008). 
non-Turkic surnames such as "Kevorkian," "Kohen" or "Papadopulos." ${ }^{32}$ Rather, it was those surnames that, by their meaning in Turkish, conveyed the idea of an (alleged) infra- or supra-national otherness, that were banned: names of foreigners, not foreign names were the target. In terms of semiotics, denotation, not connotation of the foreign, became unlawful. ${ }^{33}$

What is striking in the examples given by Şükrü Kaya, cited above, is that his move against foreignness, if assimilationist, was made with reference only to (presumably) Muslim citizens ("Ibrahim-the-Chechen," "Mehmet-the-Laz"). ${ }^{34}$ This focus is confirmed by another vivid discussion on Article 3 which took place the same day, between Kaya and Refet Bey, deputy of Bursa. The latter vehemently opposed the prohibition of "foreign names":

We will entirely abolish the names of foreign races and nations [yabancı irk ve millet isimleri* ${ }^{*}$. I am not of those who think that this is good either. As for myself, I am tired of those people who come to me in this country saying "I am one of yours" although in essence they are not [özü benden olmadığı halde]. If these people have foreign names [yabancı isim ${ }^{* *}$ ], I don't want them walking around pretending that they are Turks. If this man has the name of a foreign race, and if he is not one of mine in essence, and if he wants to bear a name that refers to his own race, then I find it convenient that he should be known for what he is, with a brand on his forehead [alnundaki damgasile].

Here I should add: those bearing names of foreign races [yabancı ırk isimleri***] or disgusting names - they will be able to change them by applying formally when it pleases them. But otherwise the spirit of the article, its purpose, is likely to be entirely missed.

32 "Papadopulos," for instance, was the most frequent surname in the Registre pour l'enregistrement des Grecs non-échangeables. Cilia Martin, "Les temps de la (re)composition urbaine à Istanbul à travers l'exemple du quartier de Kurtuluş de la fin de l'Empire ottoman à nos jours," unpublished PhD, EHESs, 2014.

33 This has been the source of recurring confusion. See, for instance, Jan Beth-Şawoce and Abdulmesih Bar Abraham, "Cumhuriyet Tarihi Boyunca Doğu ve Batı Asurlara Karşı: Baskı, Zulüm, Asimile, Kovulma ...” Fikret Başkaya and Sait Cetinoğlu (eds.), Resmi Tarih Tartışmaları 8. Türkiye'de "Azınlıklar" (Ankara: Özgür Üniversite, 2009), 221; Bouquet, Les noblesses du nom, 269; Özgül Ceren, "Legally Armenian: Tolerance, Conversion, and Name Change in Turkish Courts," Comparative Studies in Society and History 56,3 (2014): 622-49, 633 .

34 Meltem Türköz makes the same observation in Naming and Nation-Building, 149. 
Şükrü Kaya's reply was:

As to foreign names [yabancı isimler], the greatest duty of a country is to incorporate, it is to assimilate to its own community all those who live within its frontiers. (Bravos!) The opposite was true for us, and the country was dismembered. Had the Ottomans converted the people to their language and to their religion [my emphasis] in every place they went, like they did in the first period [of their history], the Danube would still be the frontier of Turkey. We suffered a great deal from that. Now, those who live here, it is our burden to force them, no matter what, into the civilization of the Turkish community, to ensure they enjoy the benefits of civilization. Why should we still call someone Mehmet-the-Kurd, Hasan-the-Circassian, or Ali-the-Laz? [...] Those differences should not remain. Should anyone still feel in their heart the slightest feeling of difference, let us erase it in schools and in social life, so that they will be just as Turkish as I am, and will serve the country. This is how so many men who belonged to foreign races came to serve the country. Why should we separate them from us? Why should we call them "Foreigner! Foreigner! Foreigner," as if their forehead was marked with a stamp of infamy [kara damga gibi alnında yabancı, yabancı, yabancı diye bulunduralım]? These differences need to be suppressed - that's what our duty is. ${ }^{35}$

Apparently, this discussion reveals the absence of consensus among the ruling elite. It looks as if Refet was more inclined to strengthen the Turks as the dominant ethno-group, hence his differentialist promotion of a well-kept onomastic domain, whereas Kaya's concern seems to be the consolidation of national unity by a Jacobin incorporation of all "foreigners" into onomastic Turkdom.

Yet, I argue that the deputy and the minister were not debating the same categories of citizens, nor the same issue in terms of semiotics. To be sure, Refet's plea lacked clarity, as he repeatedly confused connotation ("foreign names**" - whose Turkification he vehemently opposed) and denotation ("the names of foreign races" - whose Turkification he first opposed*, but ultimately supported $\left.^{* * *}\right)$. Nevertheless, when chastising "those people who come to me in this country saying 'I am one of yours' although, in essence, they are not," he was clearly not including those Muslim groups (Kurds, Laz, Circassians), whose assimilation was simply not a matter for discussion in Republican Turkey. Rather, he expressed distrust towards those non-Muslim intellectuals who had been openly inciting Turkish Armenians and Jews to change their 
names. Famous is Tekinalp's (formerly Moiz Kohen) Turkification (1928). In this book the journalist had established a new list of "Ten Commandments" for Turkish Jews, starting precisely with "Turkify your names":

It is imperative to have a Turkish name in order to be a Turk. Even your coreligionists in other countries have nationalized names for they understood this obligation. [...] Give pure Turkish names to your children who are going to be born from now on. ${ }^{36}$

Some Armenians also advocated onomastic assimilation, such as a certain Vankaya (also a pen name), as illustrated in the Istanbul Armenian-language newspaper Nor Huys (1935):

We, with our fullest existence, desire to acquire Turkish last names like the civilized Turks. We will use these last names proudly (how happy one is who says he is a Turk). We have to accomplish this task without wasting time; otherwise we will lose a great deal. For example, a sign on our shops with a Turkish last name would attract a decent Turk. Otherwise a Turk would not come near our shops unless he has to. The Turk has the right to impose this kind of conditions in order to share the rights of his country, which he has acquired with his blood. ${ }^{37}$

The assimilationist plea that Kaya delivered as a reply to Refet's anxieties should not be taken at face value either. First, his discourse, too, was ambiguous: he started by expressing his wish to see "foreign names" (connotation) disappear, but then cited only names of foreigners (denotation) as examples. Second, and more importantly, pretending not to understand whose assimilation Refet was really worried about - that of the non-Muslims - , the Interior Minister supported his assimilationist argument by once again providing examples only of citizens with a Muslim background. This "Muslims-Only" focus was further confirmed by Kaya's regret that the Ottoman conquerors had not converted everybody they had subjugated throughout their history to their language and to their religion: in this way he actually outlined what the putative limits of the national body were from the perspective of the ruling elite.

36 Quoted and translated in Yeşim Bayar, Formation of the Turkish Nation-State, 1920-1938 (New York: Palgrave Macmillan, 2014), 53-4.

37 Quoted and translated in Lerna Ekmekçioğlu, Recovering Armenia. The Limits of Belonging in Post-Genocide Turkey (Stanford: Stanford University Press, 2016), 132. 
At this point, it is in order to recall a few basics concerning the architect of the reform. Born on the island of Kos/Istanköy in 1882/1883, Şükrü Kaya graduated from the prestigious Galatasaray lyceum and Istanbul Law School, and then trained as a lawyer at the Sorbonne (1908-1912). By the time of his return the Italian occupation of the Dodecanese had forced his family to resettle in Izmir, together with thousands of Muslim refugees. He became a judge, and in this position was appointed head of the Ottoman part of the joint commission set up after the Balkan Wars to supervise the population exchange with Bulgaria. According to Erik Jan Zürcher, "it was his performance in that role that drew Talât's attention and caused him to transfer Şükrü in October to the Interior Ministry with the high rank of 'mülkiye müfettişi' or Civil Service Inspector."38 In 1914, Kaya was charged with the expulsion of the Rums of the province of Izmir. Next, he was appointed head of the Directorate for the Settlement of Tribes and Refugees of the Interior Ministry and as such "became a principal organizer of the Armenian deportations." 39 Thus, based in Aleppo from the autumn of 1915, he personally oversaw the mass murders of thousands of Armenians..$^{40}$ After the Greek-Turkish war, once he had returned from Malta where he had been exiled by the British along with many Young Turks, the Kemalists appointed him mayor of the newly reconquered (and ruined) Izmir, a place which "had been until a few weeks earlier the great metropolitan centre of Christian Asia Minor and was now the scene of a massive refugee crisis." ${ }^{41} \mathrm{He}$ also participated in the Lausanne conference, as a member of the subcommission for minorities. Finally, as Interior Minister (1927-1938), he played a prominent role in the writing of Law 2007 (June 1932), which led thousands of Istanbul Rums with Greek citizenship to leave their homes and possessions; he is also considered "responsible for the Exodus of Jews from Thrace in $1934 .{ }^{\prime 2}$ In sum, to a large extent Şükrü Kaya built his career on the ethnic engineering operations that fashioned modern Turkey.

Coming back to the exchange in the Turkish Parliament cited above, its interpretation can only be speculative. Yet I argue that, despite its apparent

38 Erik Jan Zürcher, “Unionists and Kemalists: Refugees, Killers and Nation-builders," lecture given in Cetobac Seminar Series, Paris, 15 May 2017.

39 Taner Akçam, The Young Turks' Crime Against Humanity. The Armenian Genocide and Ethnic Cleansing in the Ottoman Empire (Princeton/Oxford: Princeton University Press, 2012), 94 .

40 Idem, 444.

41 Erik Jan Zürcher, "Unionists and Kemalists."

42 Ayhan Aktar, “Turkification' policies in the Early Republican Era," Catharina Dufft (ed.), Turkish Literature and Cultural Memory "Multiculturalism" as a Literary Theme after 1980 (Wiesbaden: Harrassowitz Verlag, 2009), 29-62: 36. 
incoherence, or rather because of it, it needs to be read as some sort of a fake disagreement or a staged "dialogue of the deaf": Refet wanted to keep the nonMuslim names visible, Kaya wanted the names of the non-Turkish Muslims destroyed; in both cases, the non-Muslims remained outside onomastic Turkdom. Regarding the larger picture of Interwar Turkey one may thus assume that, if the non-Muslims were not considered when Law 2525 was passed, this was not or not only for circumstantial reasons, but because it was eventually decided that their onomastic assimilation was simply undesirable. In other words, the dominant view within the ruling elite was most probably that the non-Muslims had no place in the imagined community that the new inventory of names was expected to represent and contribute to. But why then was it announced a few months later that non-Muslims would finally have their surnames Turkified?

\section{$2 \quad$ The Etymological Turn of the Surname Reform (November 1934)}

The deputies reconvened on 1 November 1934. At the end of the month they passed two other laws which prolonged the egalitarian flavour and revolutionary style of the reform: one granted the honorific Atatürk ("Father-Turk") to Mustafa Kemal, the other made it illegal to hold titles or distinctions allegedly originating from the Ottoman past. Appellations such as ağa, hacı, hafız, hoca, kadi, bey, beyefendi, paşa, hanım, hanımefendi were abolished. Finally, on 29 November 1934 the Cumhuriyet announced that "suffixes and words expressing the idea of another nationality and taken from other languages [...]" would be banished as well (see below).

This notice must have come as a surprise to the non-Muslims. If confirmed, it apparently meant that it would be "impossible to register respectively Armenian, Bulgarian, Macedonian, Bosnian, Serbian, Croatian, and other Slavic last names, as well as Greek, Cretan, Persian, Georgian, or Arabic last names." 43 On the same page the newspaper reported that the State Council would "probably" issue the enforcement regulation of Law 2525 "within three to four days": "It is our understanding that the non-Muslims, since they are Turks, will be under the obligation to adopt surnames in the same vein. Yet, this question will be clarified once the Regulation is out." This new development was also noticed by the American chargé d'affaires in Istanbul who wrote an analysis imbued with irony:

43 Cağaptay, Islam, Secularism, and Nationalism, 62. 
With regard to the law passed in the latter part of June requiring all Turkish citizens to supply themselves with Turkish family name, persons with Greek or Armenian names will be permitted to lop the 'opoulos' and 'ians' off and so purify them. A pamphlet containing suggestions for names is to be published. ${ }^{44}$

Apparently the US diplomat thought that only "foreign" suffixes, not entire names, would be suppressed. His French counterpart was of the same opinion, and notified Paris that "minorities will be authorized to keep their names provided they cut off foreign inflexions." He even thought that "failure to do so could result in fines and prison sentences." 45

The confirmation came only three weeks later. On 19 December the Cumhuriyet reported that "surnames unrelated to Turkishness such as those ending in yan or is [would] be suppressed." The Regulation (Soyadı Kanunu Nizamnamesi) was finally issued the next day with the following articles:

Article 5. Newly adopted surnames will be chosen from the Turkish language.

Article 7. It is forbidden to bear a name appearing to contain suffixes or words [my italics] implying the idea of another nationality or borrowed from a language other than Turkish, such as Yan, Of, Ef, Viç, İç, Iss, Dis, Pulos, Aki, Zade, Mahdumu, Veled and Bin. Those who bear such names may not use them. The suffix -oğlu should be substituted in their place.

Article 8. It is forbidden to use and, once again, to bear surnames which in a general manner indicate other nationalities, such as The-Son-ofthe-Albanian [Arnavut Oğlu] or The-Son-of-the-Kurd [Kürd Oğlu], or which express the idea of another nationality, such as The-Son-ofHasan-the-Circassian [Çerkes Hasan Oğlu] or The-Son-of-Ibrahim-theBosnian [Boşnak İbrahim Oğlu], or which are borrowed from other languages, such as Zoti or Grandi. ${ }^{46}$

Article 5 implied that anyone who did not already have a surname had to pick one from the Turkish language. This confirmed that all Muslims - or at least those considered not to have a pre-Law patronymic - were to adopt a Turkish

44 NARA: Records of Foreign Service Posts, Consular Posts, Istanbul, Turkey, vol. 459.

45 Bulletin périodique de la presse turque 105, 4 (1935).

46 T.C. Resmi Gazete 2885 (20 December 1934). 
surname regardless of their ethnic our linguistic background. Article 7 stipulated that those (predominantly non-Muslims) whose patronymic name contained non-Turkish suffixes, but also "foreign" words, were to Turkify them. Finally, Article 8 reiterated that "names of tribes or foreign races and nations" were banned (as had already been stated in Article 3 of Law 2525); it also repeated almost word for word what had already been stipulated in Article 7. In sum, etymological assimilation was added to formal and semantic assimilation, and connotation of the foreign, in addition now to only its denotation, was made unlawful.

\section{Why Assimilationism Took Over Differentialism (for a While)}

A reason for this "etymological turn" of the surname reform could be its very timing. As is well known, Interwar Turkey played host to an ambitious if not demiurgic linguistic policy, self-identified as the "Language revolution." The purpose of this one-of-a-kind endeavour was no less than a radical purge of all Arabic and Persian lexical and grammatical components, which were still abundant in the written language of the literati. As a state-driven policy, the purification of the vocabulary started right after the Romanization of the alphabet (1928), but gained momentum late in 1932, a few months before the Surname Reform was launched. In November 1932 the Society for the Study of the Turkish language (SSTL, created in July 1932) initiated a nation-wide lexicographical campaign with the backing of various administrations. The purpose was to provide the etymological raw materials from which a 'Pure-Turkish' replacement lexicon was to be selected. By early 1933, citizens were encouraged to excise all 'foreign' words in oral and written practice. ${ }^{47}$

The road from words to names was short. Just as there was an impetus within official circles for a systematic cleansing of the vocabulary, the possibility to Turkify the anthroponymic landscape started to be publicly debated. Thus, on 12 January 1933 a certain Sinanoğlu published the following recommendation in the national newspaper Milliyet:

The name that really helps to distinguish individuals is the surname, and this is why we must take great care when choosing those names. Before everything, we must make sure that the surnames are absolutely Turkish. For too long people have been using surnames from foreign languages

47 Geoffrey Lewis, The Turkish Language Reform: A Catastrophic Success (Oxford: Oxford University Press, 1999). 
such as, for instance, Hanifzade or Mayorkas. ${ }^{48}$ These names need to be Turkified. Such nationalization of foreign names is frequent in other countries, and those who have nationalized their names benefit greatly from it. After the Great War, which lasted four years, this nation had to shed its blood for four more years to set up and secure its national unity. By now that it has entered a new step in building up a strong national culture, citizens should not be left free to manage their surnames themselves. $^{49}$

October-November 1934 was a climactic moment in the "Language Revolution." The results of the lexicographical campaign mentioned above had just been published, and the "war for language" was considered a new war of independence against "linguistic capitulations" (a notion applicable to common nouns and proper names alike). Thus, the new lexicon was to serve as a purified onomasticon, with lists of words eligible as future surnames abundantly displayed in the press. Mustafa Kemal himself set the tune by giving a series of notorious "Pure-Turkish" speeches, with barely any Arabic or Persian words. He also frequently rechristened people around him by giving them surnames. ${ }^{50}$ Similarly, State officials and Party members were requested not only to adopt Turkish-sounding surnames, but also to use only "Pure-Turkish" words in their official speeches and writing; every day the press of Istanbul would publish lists of "Famous people choosing Pure-Turkish words" as their new surnames. ${ }^{51}$

This purist attitude complied with the "nationalization" of other symbolic landscapes in the country. Since the mid-1920s there had been an ongoing mobilization to change any place name with a "non-national" (Greek, Armenian, Arab, Kurdish but also 'Ottoman') referent. ${ }^{52}$ Another case in point was the forbidding of shop signs written in languages other than Turkish, a policy implemented in the spring of 1933 in the neighbourhoods of Galata and Pera (Istanbul), where numerous coffee places, restaurants, wine houses, patisseries, and dancing halls had Armenian and Rum owners. ${ }^{53}$ This ambition towards

48 An Arabic word followed by a Persian suffix, Hanifzade bears a strong Islamic connotation; Mayorkas is most likely a Jewish-Turkish surname. On Sephardic Turkish family names, see Baruh B. Pinto, The Sephardic Onomasticon. An Etymological Research on Sephardic family names of the Jews living in Turkey (Istanbul: Gözlem, 2004).

49 N.H. Sinanoğlu, "Soyadı dolayında bir iki düşünce," Milliyet, 12 January 1933.

5o Szurek, "To Call a Turk a Turk."

$5^{1} \quad$ See for instance, among many other examples, Cumhuriyet, 23 November 1934.

52 Kerem Öktem, “The Nation's Imprint: Demographic Engineering and the Change of Toponymes in Republican Turkey," European Journal of Turkish Studies [Online] 7 (2008).

53 Méropi Anastassiadou, Les Grecs d'Istanbul. Histoire socioculturelle de la communauté de Péra (Leyden-Boston: Brill, 2012), 374. 
linguistic homogenization was also illustrated by the "Citizen-Speak-Turkish!" campaign. Finally, I should mention the "Law on Banning Some Attire" (3 December 1934), which forbade clerics to wear their religious garments except at shrines and during services, with the exemption of one cleric from every religion. In line with official secularism its point was to make all religions invisible. A matter of clothing, it expressed the same ambition of destruction of difference. In such collective frenzy, or yearning for purity, it is no surprise that the Surname reform, too, came to adopt a fully assimilationist orientation.

An overwhelming majority of scholars have shared the opinion that the nonMuslims were legally expected to Turkify their surnames. They base this opinion on Article 7 of the Surname Law Regulation, cited above. Alexis Alexandris was one of the first to address the question:

... after the obligatory adoption of surnames by every Turkish citizen in 1935, pressure was brought to bear upon the minorities to adopt Turkish sounding surnames. This applied particularly to the Greeks who were urged to drop from their surnames such endings as dis and poulos. ${ }^{54}$

Rifat Bali referred to Alexandris:

The Greek of Turkey would Turkify their names by dropping the '-dis' and '-pulos' suffixes. Most of the Jews would Turkify their names and surnames by finding a Turkish equivalent for each Jewish name. ${ }^{55}$

Bali further identified six Jewish citizens who, he thought, were driven to change their surnames in 1936 because of Article 7: an İsrail Kohen rechristened himself İsmail Kan, Dr Behar became Doktor Bayar, a Levi turned into a Leventer, etc. ${ }^{56}$

Quoting Alexandris and Bali, Soner Çağaptay, too, believes that Article 7 was implemented:

54 Alexis Alexandris, The Greek Minority of Istanbul and Greek-Turkish Relations, 1918-1974 (Athens: Center for Asia Minor Studies, 1983), 183.

55 Rufat Bali, "The Politics of Turkification during the Single Party Period," in Hans-Lukas Kieser (ed.), Turkey Beyond Nationalism. Towards Post-Nationalist Identities (London New York: I.B. Tauris, 2006), 45.

$5^{6}$ Bali, Cumhuriyet Yıllarında, 289. 
The statute demanded that citizens of all religious and ethnic backgrounds have Turkish last names only. This had deep repercussions amongst both Muslim and non-Muslim minorities. Scores of Jews changed not only their names, but also their first names. ${ }^{57}$

Whereas most scholars adopt a critical stance by interpreting Article 7 as a paradigmatic illustration of Turkish policies of forcible assimilation, Çağaptay sings a different tune:

Although the Kemalist ideology focused on the Turkish race, as the "Speak Turkish" campaign and the Law on Last Names demonstrated, in practice, Ankara kept the avenue of assimilation open to those who were not ethnically Turks, especially Jews and non-Turkish Muslims. Such assimilation was enforced; yet, it was inclusionary. ${ }^{58}$

Thus, in Çağaptay's representation, Turkification policies are interpreted as the cornerstone of a Turkish "desire" to include the non-Muslims, at a time where Europe was ravaged by racism:

Ankara regretted the fact that the Jews did not speak Turkish and had not assimilated. It expected that they integrate by adopting the Turkish language and Turkish names. Thus, unlike in many other interwar European countries, where racial walls divided the Jews and the Gentiles, Kemalist Turkey did not regard the Jews as racial outsiders [...]. Thus, it appears that under the rubric of Turkish race, Kemalism was willing to accept not only the Anatolian Muslims and Jews, but, wishfully, even Armenians somewhere into the body of the Turkish nation. ${ }^{59}$

Unsurprisingly, given the wide audience for his book, ${ }^{60}$ Çağaptay has inspired a few authors who also quote Article $7 \cdot{ }^{61}$ But this Alexandris-Bali-Çağaptay-

57 Cağaptay, Islam, Secularism, and Nationalism, 62.

58 Ibid., 63.

59 Ibid.

6o The same interpretation is presented in Soner Cağaptay, "Otuzlarda Türk Milliyetçiliğinde Irk, Dil ve Etnisite," Tanıl Bora (ed.), Modern Türkiye'de Siyasi Düşünce 4 (Istanbul: İletişim, 2002), 256-7.

61 Vahap Coşkun, M. Şerif Derince and Nesrin Uçarlar, Dil Yarası. Türkiye'de Eğitimde Anadilinin Kullanılmaması Sorunu ve Kürt Öğrencilerin Deneyimleri (Diyarbakır: Di̇sA, 2010), 31; Tuncay Ercan Sepetçioğlu, "Girit’ten Anadolu'ya Gelen Göçmen Bir Topluluğun Etnotarihsel Analizi: Davutlar Örneği” (Unpublished PhD, Ankara Üniversitesi, 2011), 210. 
and-beyond chain of transmission is no isolated example. Definitely a bestseller in Turkish-republican historiography (although not the first of its kind in the post-Ottoman realm ${ }^{62}$ ), Article 7 and its shiny list of suffixes is indeed cited in a large number of monographs, articles, students' essays and textbooks. ${ }^{63}$ Ahmet Ylldı's notorious opus on Turkish nationalism, for instance, has given rise to a silsila of its own: he is cited by Dilek Güven, which in turn makes it possible for Article 7 to appear on various non-academic scenes, including a human-rights report, ${ }^{64}$ and an article in Hyetert, "the only online news source for Turkey's Armenians." 65 Article 7 has also made its way into Wikipedia in Turkish, English, German, and Italian, and it is duplicated in all sorts of online media, blogs and Facebook accounts. ${ }^{6} 6$

62 A document from the Albanian Ministry of Interior (1930) mentions that, at the time of Austro-Hungarian occupation of Albania (1916-1918), there had already been an attempt to ban surnames ending in $i q, v i c ̧, e v, o f$, is, os, aqi, and dhis. Nathalie Clayer, "Un élément sur la nationalisation des noms dans l'Albanie de l'entre-deux-guerres," in Christian Müller and Muriel Roiland-Rouabah (eds.), Les non-dits du nom. Onomastique et documents en terre d'Islam. Mélanges offerts à Jacqueline Sublet (Damas-Beyrouth: Presses de l'IFPO, 2013), 470.

63 Ahmet Ylldı, "Ne Mutlu," 236; Dilek Güven, 6-7 Eylül Olayları (Istanbul: Tarih Vakfi, 2005), 90; Fabio Salomoni, "Balkan Migrations to Modern Turkey: Continuity and Change," in Luisa Chiodi (ed.), The Borders of the Polity. Migration and Security across the EU and the Balkans (Ravenna: Longo, 2005), 148; İbrahim Aksu, The Story of Turkish Surnames: An Onomastic Study of Turkish Family Names, their Origins and Related Matters 1 (Çanakkale: s.n., 2006), 35; Serap Yeşiltuna, "1934 İskân Kanunu ve basındaki yansımaları" (Master's Thesis, İstanbul Üniversitesi, 2006), 79; Meltem Türköz, "Surname Narratives and the State-Society Boundary: Memories of Turkey's Family Name Law of 1934," Middle Eastern Studies 43,6 (2007): 895; Yasemin Doğaner, "An Identity Construction in the Turkish Republic: The Law on Family Names," Wiener Zeitschrift für die Kunde des Morgenlandes 99 (2009): 120; Mehmet Cem Ulugöl, "Osmanlı ve Türkiye'de Vatandaşlık Kavramı, Azınlıklar Üzerinde Etkisi ve Uygulamaları” (Master's Thesis, İstanbul Bilgi Üniversitesi, 2009), 87; Uğur Ümit Üngör, The Making of Modern Turkey. Nation and State in Eastern Anatolia, 1913-1950 (Oxford - New York: Oxford University Press, 2011), 231; Klaus Kreiser, Geschichte der Türkei. Von Atatürk bis zur Gegenwart (Munich: C.H. Beck, 2012), 75; Ekmekçioğlu, "Republic of Paradox," 672; Türköz, Naming and Nation-Building, passim.

64 Elçin Aktoprak, Bir 'Kurucu Öteki' Olarak: Türkiye'de Gayrimüslimler (Ankara: інм, 2010), 26.

65 Murat Bebiroğlu, "Cumhuriyet Döneminde Patrikler ve Önemli Olaylar" (2009). Accessed 29 March 2019. https://hyetert.org/2009/05/26/cumhuriyet-doneminde-patrik ler-ve-onemli-olaylar/.

66 Serdar Kaya, "Soyadı Kanunu ve Türkleştirme Politikaları/Ahmet Yıldız" (2009), www.po maklar.com/t710-soyady-kanunu-ve-turkletirme-politikalary-ahmet-yyldyz\#1852; Anon., "21 Haziran 1934: Bir Asimilasyon Aracı Olarak Soyadı Kanunu” (2013), pomaknews .com/?p=8965; Anon., "Türkleş(tir)menin Tarihi” (2013), https://www.turkish-media.com/ forum/topic/321603-turklestirmenin-tarihi; Roni Margulies, "Huristiyan ve Yahudilere karşı tedbirli davranma ihtiyacı" (2014), http://www.duzceyerelhaber.com/ronimargulies/21852-hiristiyan-ve-yahudilere-karsi-tedbirli-davranma-ihtiyaci; Birleşmiş 
The problem is that Article 7 is discordant with what anyone who has ever stayed in Istanbul knows empirically: namely, that a significant proportion of the non-Muslims have conserved their pre-Law "foreign" family names. Very few authors have addressed this contradiction. Murat Bebiroğlu admits that, "for unknown reasons," Article 7 was not implemented "in certain areas," where the suffix -yan survived ${ }^{67}$ Meltem Türköz explains that "as recognized minorities, the Jewish, Armenian and Greek populations were not legally bound to change names, but this was not made explicit," 68 in other words that "the law was not meant to encompass the minorities," ${ }^{69}$ but does not say why. Özgül Ceren has a convoluted argument: "This right [to take non-Turkish names] was not protected by law, however, the law allowed recognized 'minorities' to adopt their 'religious and cultural' names simply by not explicitly forbidding them to do so." ${ }^{70}$ Finally, Lerna Ekmekçioğlu sees the issue, but does not sort it out either: "from anecdotal evidence it appears that Armenians in Istanbul had kept their original last names while those in Anatolia changed them. But even in Istanbul, while some non-Muslim families kept their ethnic last names, some chose to Turkify them, some were forced to Turkify them, while others simply dropped the linguistic patronymic ending. The only extensive study thus far on the Surname Law [that of Meltem Türköz] does not solve this puzzle."71 Well, one missing piece here is the fact that Article 7 was abandoned and replaced four days after it had come into existence. In the sinuous history of the Surname reform, this is yet another turn which has gone almost unnoticed, and was never explained. ${ }^{72}$

Beyinler, "Soyadı Kanunu" (2017), https://facebook.com/birlesmis.beyinler/photos/a.172 0115484934734.1073741838.17066537462809o8/1922592824686998/?type $=3 \&$ source $=48 \&$ _ tn_=EHH-R.gazetevatan.com/soyadi-kanunu-ne-zaman-cikarildi-1143782-gundem. All links accessed 29 March 2019.

67 Bebiroğlu, "Cumhuriyet."

68 Türköz, "Surname Narratives," 901.

69 Türköz, Naming and Nation-Building, 148.

$70 \quad$ Ceren, "Legally Armenian," 634.

71 Ekmekçioğlu, Recovering Armenia, 192.

72 One study does notice the modification, yet without addressing its causes and implications: Sabit Dokuyan, "Soyadı Kanunu ve Kanunun Uygulanma Süreci," Tarih İncelemeleri Dergisi 31,1 (2016): 146. The accurate version of Article 7 is quoted in Temuçin F. Ertan, "Cumhuriyet Kimliği Tartışmasının Bir Boyutu: Soyadı Kanunu," Kebikeç 10 (2000): 255-72; Elçin Macar, Cumhuriyet Döneminde İstanbul Rum Patrikhanesi (Istanbul: İletişim, 2012/2003); İrem Aki, "Yabancı Irk ve Millet İsimleriyle Soyadı Alınmasi Yasağı ve Anayasa Mahkemesi," Türkiye Barolar Birliği Dergisi 121 (2015): 403-20. 


\section{Onomastics Meets Geopolitics. The Differentialist Turn of the Reform (December 1934)}

On 30 December 1934, the Cumhuriyet discreetly reported that "amendments" (tadilât) had been made to the regulation, of which they had been notified "by telephone from Ankara." At that point a new regulation had in fact already been adopted (24 December), and circulated in the Official Journal (27 December). Instead of the original Article 7 , and its alluring list of banned suffixes, one now read: "The names of foreign races and nations may not be used as surnames." ${ }^{73}$ This was a radical reversal: non-Turkic suffixes and words were no longer unlawful; and denotation, again, not connotation (of the foreign), was the only legal offence. As a result, the Turkish anthroponymic landscape could be expected to change from a heterogeneous and multilingual, but also poly-systemic, marquetry of names to a formally unified (first name + surname), yet etymologically dual, onomastic system - with virtually all Muslims bearing "Pure-Turkish" surnames and all non-Muslims retaining their non-Turkic surnames: ${ }^{74}$ minoritization prevailed over Turkification.

Determining the reasons for this new differentialist turn requires sources other than Turkish: the Francophone daily newspaper Istanbul, known to be subsidized by the French Embassy and a well-informed outlet on minoritiesrelated issues, and the Greek-speaking Apoyevmatini, the leading newspaper of Istanbul's Rums, have proved essential here. According to the Istanbul, the Greek Government was involved. Right after the (first) regulation was issued, the Greek Ministry of Foreign Affairs Dimitrios Maximos approached the Ambassador of Turkey in Athens, Ruşen Eşref [Ünaydın], in order to protest that the Turkification of the Rum surnames did not comply with earlier commitments by the Turkish Minister of Foreign Affairs, Tevfik Rüştü [Aras]. Apparently, the Turks reacted swiftly. On 24 December, Maximos announced that Turkey would respect its commitments, and the next day the Istanbul was first to announce upcoming modifications. ${ }^{75}$ Finally, on $3^{1}$ December, Ruşen Eşref visited Maximos in person to inform him of the new regulation. The next day, Maximos made a public statement that the issue was closed. ${ }^{76}$

73 T.C. Resmi Gazete 2891 (27 December 1934). In other words, the new Article 7 was only a variation on Article 3 of Law 2525; Article 8 was modified to the exact same effect.

74 Unless they would individually decide to change their surname, a possibility that remained open. See Élise Massicard, "Post-hérité. Un retour du patronyme en Turquie contemporaine?" Revue d'histoire moderne et contemporaine, 6o,2 (2013): 87-105; Özgül Ceren, "Legally Armenian"; Türköz, Naming and Nation-Building, 167.

75 Istanbul, 25 December 1934.

76 Istanbul, 2 and 3 January 1935 . 
The 1930s was a time of rapprochement between Athens and Ankara, as illustrated by the "friendship convention" signed in October 1930. This amitié gréco-turque had been reinforced by the Balkan Pact (October 1934), a treaty signed by Greece, Romania, Turkey, and Yugoslavia which aimed at appeasing remaining tensions related to minorities, the post-War exchanges of populations, and property-related issues. Both Tevfik Rüştü and Maximos had been personally involved in this negotiation. Like all other newspapers in Turkey, the Apoyevmatini published the initial regulation. ${ }^{77}$ It also extensively reported how the overall Turkish "purification" project of language and onomastics was viewed with approval in other Balkan countries. ${ }^{78}$ It was only on 3 January 1935 that the Rum newspaper reported extensively on the new regulation. First, it cautiously cited the Kathimerini, an Athenian newspaper: "This measure will be appreciated by the Greek people who will consider the Greek-Turkish friendship as restored on the basis of mutual comprehension and solidarity." The Apoyevmatini then commented: "this decision by the Government of Ankara created a better atmosphere of dialogue regarding all minorities-related issues of both countries, and reaffirms the precious and solid friendship in favour of the consolidation of peace in the Balkans. ${ }^{79}$ It is possible that the Muslim Greek citizens of Western Thrace were indeed used as a leverage by Athens to pressure Ankara: leave "our" Rums alone and "your" Turks will be fine. What we know for sure is that the local question of the Turkish Rums' surnames was now embedded in international politics. This does change the picture significantly: Ankara was not alone in deciding whether Istanbul Rums were to be onomastically assimilated or not, thus confirming the status of Turkish Rums (and Greek Muslims) as "hostage minorities." ${ }^{80}$ But then Turkish Armenians and Jews were potential collateral victims of this relationship: they had no back-up country that could pull diplomatic strings in their favour, and were directly affected by the ups-and-downs of the Greek-Turkish interaction. ${ }^{81}$

77 Apoyevmatini, 21 December.

78 Apoyevmatini, 22 December.

79 Apoyevmatini, 3 January 1935.

8o Stefanos Katsikas, "Hostage minority. The Muslims of Greece (1923-41)," in Benjamin Fortna, Stefanos Katsikas, Dimitris Kamouzis and Paraskevas Konortas eds., State-Nationalisms in the Ottoman Empire, Greece and Turkey (New York: Routledge, 2013), 153-75; Emre Öktem, "The Legal Notion of Nationality in the Turkish Republic: from Ottoman Legacy to Modern Aberrations," Middle Eastern Studies 53,4 (2017): 638-55.

81 This could explain why only few Rums decided to Turkify their surname but many Jews and Armenians did (or were driven to). This initially speculative impression was confirmed to me by Cilia Martin, to whom I express my thanks. See also the case, in the 1940s, of a citizen who "was first named Vardar 'by mistake,' but wanted to take back his old family name of Evrenos." Türköz, Naming and Nation-Building, 167. 
In spite of this, the Turkish Cabinet should by no means be considered a puppet in the hands of Athens. For this was not the first time the Greek attempted to influence Ankara's decisions. Just a few days before, for instance, Athens had attempted to have the "Law on Banning Some Attire" (published on 13 December 1934) amended in favour of the Orthodox popes. ${ }^{82}$ The Patriarchate of Istanbul protested, and the Greek Prime Minister Panagis Tsaldaris launched a press campaign in Athens: "We will take intensive diplomatic actions towards Ankara if necessary. Enforcing this law would be a heavy assault against the emotions of the whole Orthodoxy."83 Any actions taken were in vain: the law was enforced as from June 1935, as planned. Another example is Athens' failure to have the "Law Reserving Certain Professions, Trades, and Services to Turkish Citizens" amended. Passed in June 1932, and enforced from June 1934, this law forbade permanent residents to practice a wide range of professions, from street vendor to hairdresser, janitor, worker, or employee. The main target of the law - whose architect was again Şükrü Kaya - were precisely those Rums of Istanbul who, although Greek subjects, were predominantly natives of Constantinople, and had therefore been exempted from the population exchange of 1923. Despite many protestations, Athens proved unable to alter the law, and thousands of Rums lost their jobs and were forced to leave Turkey. ${ }^{84}$ Thus, it would probably be a mistake to see Ankara's change of policy with regard to the surname reform as the mere effect of Athens' intervention. Rather, we should think of two national governments converging in the idea that Turkish Rums were not to be assimilated to the majority of the country they lived in. Minoritarization was a transnational dynamic.

\section{Consistency in Inconsistency. The Art of the Legal Duality of the Turkish State (January 1935 and Beyond)}

Measuring the extent to which the non-forbidding of non-Turkish surnames was actually enforced would go beyond the scope of this study. However, some remarks regarding the ongoing elaboration of the normative apparatus of the reform after its implementation had started are in order. Two distinct regulations, as we have seen, had been issued in the Official Journal within a week of each other (20 and 27 December). This documentation was also published

\footnotetext{
$82 \quad$ T.C. Resmi Gazete 2879 (3 December 1934).

83 Elçin Macar, "The Policies of Turkey toward the Ecumenical Patriarchate: The Single-party Era (1923-45)," Benjamin Fortna et al. eds, State-Nationalisms, 132-52.

84 Aktar, "Cumhuriyetin."
} 
through private brochures. Some were printed immediately after the release of the first regulation, and thus became partly obsolete while already commercially distributed..$^{85}$ Another source of confusion was added by the Turkish administration itself, as illustrated by İdare, the Turkish government journal. Issued by the Interior Ministry, this monthly outlet published newly issued legislation, along with international comparative studies on various administrative questions. In February 1935, Iddare published a new piece related to the reform: the Surname rulings (Soyadı Talimatnamesi). Originally circulated on 2 January $1935,{ }^{86}$ this document was meant to provide municipalities and civil agents with guidelines for the enforcement of the regulation, which had just officially started. But, apparently, the department which wrote this document did not know that the regulation had been modified, for it referred to the obsolete regulation (numbered 2/1720), not the one in effect (numbered $2 / 1759$ )! To quote:

According to Articles 1 and 3 of the law, and Articles 5 and 7 of the regulation, they may not record surnames which are not taken from the Turkish language or surnames implying the idea of another nationality. ${ }^{87}$

This clearly sounded as a conscious re-enactment of the assimilationist ambition to purge the country of all "foreign" surnames. And so, Article 7 was resuscitated from the dead.

In the meantime, the rulings were very vague on the question of which suffixes were actually prohibited:

Since according to Article 6 of the regulation only the use of the surname as such, or with the word $o g \breve{l} u$, is accepted, it is forbidden to use, instead of $o g ̆ l u$, a word or a suffix which would convey the same meaning in any [other] language, such as zade or mahdumu. And those [words or suffixes] may not be recorded in civil registers or in birth certificates. ${ }^{88}$

85 An example is The Surname Law and its Regulation, a booklet available for 5 kuruş at İnkilâp Kitaphanesi (the "Library of the Revolution"), in the heart of Old Stambul's administrative district. [Anon.] Soy Adı Kanunu ve Nizamnamesi. Resmî Gazetenin 20 Kânunuevvel 1934 tarih ve 2885 sayılı nüshasından alınmıştır ([Istanbul]: Necmistikbal Matbaasi, 1934).

86 This date is taken from T.C. Dahiliye Vekâleti, Nüfus İşleri Umum Müdürlüğü Neşriyatı, Nüfus Kılavuzu. Hizmete Mahsus (Istanbul: Cumhuriyet Matbaası, 1938), 59.

87 İdare. Dahiliye Vekâleti Aylık Mecmuası 83, 357.

88 Ibid. 
Strangely enough, the "Muslim-centred" zade and mahdum were duly mentioned as banned, but not the other, "Christian-related" suffixes. What is more, the prohibition of zade and mahdum was justified by the unchanged Article $6^{89}$ of the (first and second) regulations - not by Article 7. This raises speculation that the authors were in fact aware of a reversal of Article 7. If we leave aside speculation, what remains is that in practice legal duality set in: any agent confronted with Kevorkians, Papapulos, or Kohens could either accept or refuse to register their surnames, depending on whether he relied on the Minister's rulings or the regulation by the Government. This ambiguity is probably what explains the existence of yet another layer of documentation: a circular from the Interior Ministry, dated 16 April 1935, of which we have only indirect knowledge, as it was quoted within a correspondence (itself cited by Meltem Türköz) between two civil agents in Istanbul:

This document has been turned back after having gone over the Interior Ministry's circular on the surnames of Christians dated 16/4/935 and numbered 4892 that was distributed to all the districts. In this circular it says: These [people] already have surnames and because of this it is not mandatory for them to have a Turkish name or for them to remove additions to their names such as yan, $d^{2} z^{90}$ or aki. Actually every Christian family carries a registered or unregistered surname.... We are registering the surnames of non-Muslims in their own language without hesitation based on the judgement of this order. [...] We insist that this surname can be registered. If you are insisting on objecting then you may appeal to the higher authorities $\left[\ldots . .{ }^{91}\right.$

This (new) differentialist stance with regard to "the Christians" was against the rulings of January but complied with the regulation and the promises made to Athens in late December. And so, Article 7 died again.

89 "The Surname can be used either alone or with oğlu."

9o I do not know whether this typo was made by the author of the letter or by Meltem Türköz.

91 Correspondence quoted and translated in Türköz, Naming and Nation-Building, 109. Unfortunately, the author does not specify in which archive she found this letter, nor does she mention its chronological and institutional whereabouts. She interprets it by pointing "to the lack of standard communication among the population offices concerning procedures for minorities": although certainly valid, the argument is limited because she ignores the fluctuations inherent in the existence of two distinct regulations, and does not refer to the rulings either. 
A last speculation is in order before this chapter is closed. If the instructions above were applied in all the districts of Istanbul, what about the rest of the country? 1930s Istanbul was still a place where tens of thousands of nonMuslims could feel "at home," with a dense network of organisations. This density itself made enforced Turkification difficult, notwithstanding the fact that Turkish administrative practices were visible to many foreigners. In Anatolia and Thrace, on the other hand, the remaining Armenian and Jewish communities and institutions were scattered and weakened by a decade of lowintensity persecutions. There, the state could act without much accountability, while the non-Muslims themselves had every reason to blend in. One may thus assume that the Interior ministry played a differentialist card in Istanbul, while keeping an assimilationist stance in Anatolia. With the current state of knowledge only few clues are available. Nicole Lapierre reports the memories of an Avedikian who became Avedikoğlu (still not a Turkish-sounding name, though). He remembered being told at the registry office in Sivas, "there is no more yan, it's over." ${ }^{\prime 2}$ Meltem Türköz studies the case of the Divans (formerly Divanyans), a family from Merzifon whose men were killed during the genocide, and whose factory was confiscated after the war: "It was better, then, not to have it [the -yan]. ${ }^{93}$ From the population registers Türköz further concludes that among Istanbul's Armenians "name changes were more frequently made among those who were displaced from Anatolia." ${ }^{94}$ Lerna Ekmekçioğlu makes a similar observation. ${ }^{95}$ Finally, and most significantly, it seems that the assimilationist rulings of January 1935 remained in effect despite the differentialist instructions of April: indeed, they still appeared in an official guidebook issued by the Interior Ministry for Registry officials in $1938 .{ }^{96}$ In other words, my suspicion is that even after the legislative jumble of 1934-1935, Article 7 remained both dead in Istanbul and alive in the rest of the country, making it a state-of-the-art illustration of legal duality, if not actual duplicity (should this legal duality be subsequently found to be the effect of a definite policy). ${ }^{97}$

\footnotetext{
92 Lapierre, Changer de nom, 183.

93 Türköz, Naming and Nation-Building, 150.

94 Ibid., 177.

95 Ekmekçioğlu, Recovering Armenia, 192.

96 T.C. Dahiliye Vekâleti, Nüfus Kılavuzu, 59-70.

97 Something which the current conditions of access to Turkish Interior and Foreign Affairs archives did not allow me to do.
} 
First, contrary to what has been asserted for decades, Turkish Armenians, Jews and Rums were not expected by law to alter their surname. Thus, not only did many of them remain visible after the reform, but they ended up even more visible because of the Turkification of the rest of the anthroponymic landscape. From the perspective of the ruling elite this differentialist option makes sense in a context of enduring discriminations against the non-Muslims, and within the broader Young-Turk habitus of postgenocidal Turkey. ${ }^{98}$ But it was simultaneously the effect of international politics, as Athens and Ankara converged in a common understanding of their countries as religion-based polities, with well-circumscribed "minorities." In other words, minoritization was both a domestic, i.e., post-genocidal, and a transnational, i.e., post-Ottoman dynamic.

Second, in public-policy analysis, and this goes for Turkey as well, ${ }^{99}$ it is customary to explain the incoherence of the state by the fact that public action always leaves room for contradictory rationales and practices, involving multiple actors. The Surname reform certainly illustrates this axiom. For instance, the short-lived ambition to entirely "purify" onomastics in Turkey could have led to a different outcome in terms of nation building, and probably also had important ground-level consequences. But the question of state inconsistency here requires a different argument. For, what I hope to have demonstrated is that the variability of the reform was not (only) inherent in its circumstantial implementation, but right from, and throughout, its legal and paralegal elaboration.

Within a short time the non-Muslims were given a series of contradicting injunctions, which could be summarized as follows: "You would do well to abandon your surnames" (various voices, from 1928 to 1934). "You are under no obligation to change your name" (the law, June 1934). "In fact, you'll have to do it." (first regulation, December 1934). "Well, it turns out you don't" (second regulation, December 1934). "But, of course, you do" (rulings, January 1935) "Wait. No, you don't" (Istanbul, April 1935) - "except if you do" (still the rulings, 1938). Beyond the question of whether names were changed or not - some

\footnotetext{
98 Suciyan, The Armenians.

99 See for instance Senem Aslan, "Incoherent State: The Controversy over Kurdish Naming in Turkey," European Journal of Turkish Studies [Online] 10 (2009); Benjamin Gourisse, "Order and Compromise: The Concrete Realities of Public Action in Turkey and the Ottoman Empire," in Marc Aymes, Benjamin Gourisse and Elise Massicard (eds.), Order and Compromise: Government Practices in Turkey from the Late Ottoman Empire to the Early 21st Century (Leiden: Brill, 2015), 1-24.
} 
were, some were not - , the individuals concerned must have come out of the whole process with an increased feeling of existential precariousness.

Finally, what this legal volatility revealed, in its very consistency - again, whether intentional or not - is that Turkey's ruling elite could hardly make up its mind about what to do with the non-Muslims, and thus left them in a sort of political limbo where they remained neither insiders nor outsiders. A good illustration of this is that they could alternatively be accused of unduly Turkifying their surname with treacherous purposes, ${ }^{100}$ but also be blamed for not doing that and thus "disregard the law by doing just what pleases them."101 Damned if you do, damned if you don't.

\section{Bibliography}

About, Ilsen, and Vincent Denis. Histoire de l'identification des personnes. Paris: La Découverte, 2010.

Akçam, Taner. The Young Turks' Crime Against Humanity. The Armenian Genocide and Ethnic Cleansing in the Ottoman Empire. Princeton/Oxford: Princeton University Press, 2012.

Aki, İrem. "Yabancı Irk ve Millet İsimleriyle Soyadı Alınmasi Yasağı ve Anayasa Mahkemesi." Türkiye Barolar Birliği Dergisi 121 (2015): 403-20.

Aksu, İbrahim. The Story of Turkish Surnames: An Onomastic Study of Turkish Family Names, their Origins and Related Matters 1. Çanakkale: s.n., 2006.

Aktar, Ayhan. “Cumhuriyetin ilk yıllarında uygulanan 'Türkleştirme' Politikaları," Tarih ve Toplum 156 (1996): 4-18.

Aktar, Ayhan. “'Turkification' policies in the Early Republican Era." In Turkish Literature and Cultural Memory "Multiculturalism" as a Literary Theme after 1980, edited by Catharina Dufft, 29-62: 36. Wiesbaden: Harrassowitz Verlag, 2009.

Aktoprak, Elçin. Bir 'Kurucu Öteki' Olarak: Türkiye'de Gayrimüslimler. Ankara: інм, 2010.

Alexandris, Alexis. The Greek Minority of Istanbul and Greek-Turkish Relations, 19181974. Athens: Center for Asia Minor Studies, 1983.

Anastassiadou, Méropi. Les Grecs d'Istanbul. Histoire socioculturelle de la communauté de Péra. Leyden-Boston: Brill, 2012.

Aslan, Senem. “Citizen, Speak Turkish!': A Nation in the Making," Nationalism and Ethnic Politics 13,2 (2007): 245-72.

100 Eissenstat, "Metaphors," 253.

101 Ali Rıza Önder, "Soyadlarımız Üzerine," Türk Dili 201 (1968): 317. 
Aslan, Senem. "Incoherent State: The Controversy over Kurdish Naming in Turkey." European Journal of Turkish Studies [Online] 10 (2009).

Baer, Marc. "The Double Bind of Race and Religion: The Conversion of the Dönme to Turkish Secular Nationalism." Society for Comparative Study of Society and History 46,4 (2004): 682-709.

Bali, Rıfat. Cumhuriyet Yıllarında Türkiye Yahudileri. Bir Türkleştirme Serüveni (19231945). Istanbul: İletişim, 1999.

Bali, Rufat. "The politics of Turkification during the Single Party period." In Turkey Beyond Nationalism. Towards Post-Nationalist Identities, edited by Hans-Lukas Kieser, 43-9, London - New York: I.B. Tauris, 2006.

Bali, Rıfat. 1934 Trakya Olayları. Istanbul: Kitabevi, 2008.

Bayar, Yeşim. Formation of the Turkish Nation-State, 1920-1938. New York: Palgrave Macmillan, 2014.

Bayır, Derya. Minorities and Nationalism in Turkish Law. New York: Routledge, 2016 (2013).

Bebiroğlu, Murat. "Cumhuriyet Döneminde Patrikler ve Önemli Olaylar" (2009). Accessed 29 March 2019. https://hyetert.org/2009/05/26/cumhuriyet-doneminde -patrikler-ve-onemli-olaylar/.

Benramdane, Farid. “Qui es-tu? J'ai été dit. De la destruction de la filiation dans l'état civil d'Algérie ou éléments d'un onomacide sémantique." Insaniyat 10 (2000): 79-87.

Beth-Şawoce, Jan, and Abdulmesih Bar Abraham. "Cumhuriyet Tarihi Boyunca Doğu ve Batı Asurlara Karşı: Baskı, Zulüm, Asimile, Kovulma ...” In Resmi Tarih Tartışmaları 8. Türkiye'de “Azınlıklar," edited by Fikret Başkaya and Sait Cetinoğlu. Ankara: Özgür Üniversite, 2009.

Beyinler, Birleşmiş. "Soyadı Kanunu" (2017). Accessed 29 April 2019. https://face book.com/birlesmis.beyinler/photos/a.1720115484934734.1073741838.17066537462 $80908 / 1922592824686998 /$ ?type $=3 \&$ source $=48 \& \_$tn__ $=$EHH-R.gazetevatan $. c o m /$ soyadi-kanunu-ne-zaman-cikarildi-1143782-gundem.

Bouquet, Olivier. "Onomasticon Ottomanicum: identification administrative et désignation sociale dans l'État ottoman du XIX ${ }^{\mathrm{e}}$ siècle." Revue des mondes musulmans et de la Méditerranée 127 (2010): 21335.

Bouquet, Olivier. Les noblesses du nom. Essai d'anthroponymie ottoman. Turnhout: Brepols, 2013.

Büyüksaraç, Güldem Baykal, and Jonathan Glasser. "Inhabiting the Margins: Middle Eastern Minorities Revisited." Anthropological Quarterly 90,1 (2017): 5-16.

Büyüksaraç, Güldem Baykal. "Trans-border Minority Activism and Kin-state Politics: The Case of Iraqi Turkmen and Turkish Interventionism." Anthropological Quarterly 90,1 (2017): 17-54.

Cağaptay, Soner. “Otuzlarda Türk Milliyetçiliğinde Irk, Dil ve Etnisite." In Modern Türkiye'de Siyasi Düşünce 4, edited by Tanıl Bora, 245-61. Istanbul: İletişim, 2002. 
Cağaptay, Soner. Islam, Secularism, and Nationalism in Modern Turkey. Who is a Turk? New York: Routledge, 2006.

Ceren, Özgül. "Legally Armenian: Tolerance, Conversion, and Name Change in Turkish Courts." Comparative Studies in Society and History 56,3 (2014): 622-49.

Chehabi, Houchang E. "The reform of Iranian nomenclature and titulature in the fifth Majles." In Converging Zones: Persian Literary Tradition and the Writing of History: Studies in Honor of Amin Banami, edited by Wali Ahmadi, 84-116. Costa Mesa: Mazda Publishers, 2012.

Clayer, Nathalie. "Un élément sur la nationalisation des noms dans l'Albanie de l'entre-deux-guerres." In Les non-dits du nom. Onomastique et documents en terre d'Islam. Mélanges offerts à Jacqueline Sublet, edited by Christian Müller and Muriel Roiland-Rouabah, 469-79. Damas-Beyrouth: Presses de l'IFPO, 2013.

Clayer, Nathalie. "The Muslims in South-Eastern Europe. From Ottoman Subject to European Citizens." In Routledge Handbook of Islam in the West, edited by Roberto Tottoli, 70-84. New York: Routledge, 2015.

Coşkun, Vahap, M. Şerif Derince, and Nesrin Uçarlar, Dil Yarası. Türkiye'de Eğitimde Anadilinin Kullanılmaması Sorunu ve Kürt Öğrencilerin Deneyimleri. Diyarbakır: DisA, 2010.

Cowan, Jane K. "Ambiguities of an Emancipatory Discourse: the Making of a Macedonian Minority in Greece." In Culture and Rights. Anthropological Perspectives, edited by Jane K. Cowan, Marie-Bénédicte Dembour and Richard A. Wilson, 152-76. Cambridge: Cambridge University Press, 2001.

Dağtaş, Mahiye Seçil. "Heterogeneous Encounters: Tolerance, Secularism and Religious Difference in Turkey's Border with Syria." Unpublished PhD, University of Toronto, 2014.

Doğaner, Yasemin. "An Identity Construction in the Turkish Republic: The Law on Family Names." Wiener Zeitschrift für die Kunde des Morgenlandes 99 (2009):113-25.

Dokuyan, Sabit. "Soyadı Kanunu ve Kanunun Uygulanma Süreci." Tarih İncelemeleri Dergisi 31,1 (2016): 129-66.

Eissenstat, Howard. "Metaphors of Race and Discourse of Nation: Racial Theory and the Beginnings of Nationalism in the Turkish Republic." In Race and Nation: Ethnic Systems in the Modern World, edited by Paul Spickard, 239 56. New York: Routledge, 2005 .

Ekmekçioğlu, Lerna. "Republic of Paradox: The League of Nations Minority Protection Regime and the New Turkey's Step-Citizens." International Journal of Middle East Studies 46,4 (2014): 657-79.

Ekmekçioğlu, Lerna. Recovering Armenia. The Limits of Belonging in Post-Genocide Turkey. Stanford: Stanford University Press, 2016.

Ertan, Temuçin F. "Cumhuriyet Kimliği Tartışmasının Bir Boyutu: Soyadı Kanunu." Kebikeç 10 (2000): 255-72. 
Goalwin, Gregory J. "Understanding the exclusionary politics of early Turkish nationalism: an ethnic boundary-making approach." Nationalities Papers 45,6 (2017): $1150-66$.

Gourisse, Benjamin. "Order and Compromise: The Concrete Realities of Public Action in Turkey and the Ottoman Empire." In Order and Compromise: Government Practices in Turkey from the Late Ottoman Empire to the Early 21st Century, edited by Marc Aymes, Benjamin Gourisse and Elise Massicard, 1-24. Leiden: Brill, 2015.

Güven, Dilek. 6-7 Eylül Olayları. Istanbul: Tarih Vakfi, 2005.

Katsikas, Stefanos. "Hostage minority. The Muslims of Greece (1923-41)." In State-Nationalisms in the Ottoman Empire, Greece and Turkey, edited by Benjamin Fortna, Stefanos Katsikas, Dimitris Kamouzis and Paraskevas Konortas, 153-75, New York: Routledge, 2013.

Kaya, Serdar. "Soyadı Kanunu ve Türkleştirme Politikaları/Ahmet Yıldız" (2009). Accessed 29 April 2019. www.pomaklar.com/t710-soyady-kanunu-ve-turkletirme -politikalary-ahmet-yyldyz\#1852.

Kezer, Zeynep. Building Modern Turkey. State, Space, and Ideology in the Early Republic. Pittsburgh: University of Pittsburgh Press, 2015.

Kreiser, Klaus. Geschichte der Türkei. Von Atatürk bis zur Gegenwart. Munich: C.H. Beck, 2012.

Lamprou, Alexandros. "Nationalist Mobilization and State-Society Relations: The People's Houses' Campaign for Turkish in Izmir, June-July 1934." Middle Eastern Studies 49,5 (2013): 824-839.

Lapierre, Nicole. Changer de nom. Paris: Stock, 1995.

Lewis, Geoffrey. The Turkish Language Reform: A Catastrophic Success. Oxford: Oxford University Press, 1999.

Macar, Elçin. "The Policies of Turkey toward the Ecumenical Patriarchate: The Single-party Era (1923-45)." In State-Nationalisms in the Ottoman Empire, Greece and Turkey, edited by Benjamin Fortna, Stefanos Katsikas, Dimitris Kamouzis and Paraskevas Konortas, 132-52. New York: Routledge, 2013.

Macar, Elçin. Cumhuriyet Döneminde İstanbul Rum Patrikhanesi. Istanbul: İletişim, 2012 (2003).

Maksudyan, Nazan. "The Turkish review of anthropology and the racist face of Turkish Nationalism," Cultural Dynamics 17,3 (2005): 291-322.

Margulies, Roni. "Hıristiyan ve Yahudilere karşı tedbirli davranma ihtiyacı" (2014). Accessed 29 April 2019. https://duzceyerelhaber.com/roni-margulies/21852 -hiristiyan-ve-yahudilere-karsi-tedbirli-davranma-ihtiyaci.

Martin, Cilia. "Les temps de la (re)composition urbaine à Istanbul à travers l'exemple du quartier de Kurtuluş de la fin de l'Empire ottoman à nos jours." Unpublished PhD, EHESs, 2014. 
Massicard, Élise. "Post-hérité. Un retour du patronyme en Turquie contemporaine?" Revue d'histoire moderne et contemporaine 60,2 (2013): 87-105.

Noiriel, Gérard, ed. L'identification. Genèse d'un travail d'État. Paris: Belin, 2007.

Öktem, Kerem. “The Nation's Imprint: Demographic Engineering and the Change of Toponymes in Republican Turkey." European Journal of Turkish Studies [Online] 7 (2008).

Öktem, Emre. "The Legal Notion of Nationality in the Turkish Republic: from Ottoman Legacy to Modern Aberrations." Middle Eastern Studies 53,4 (2017): 638-55.

Önder, Ali Rıza. “Soyadlarımız Üzerine.” Türk Dili 201 (1968): 307-17.

Oran, Baskın. Türkìye'de Azınlıklar: Kavramlar, Teori, Lozan, İç Mevzuat, İçtihat, Uygulama. Istanbul: İletişim Yayınları, 2005 (2004).

Pinto, Baruh B. The Sephardic Onomasticon. An Etymological Research on Sephardic family names of the Jews living in Turkey. Istanbul: Gözlem, 2004.

Provence, Michael. "Ottoman Modernity, Colonialism, and Insurgency in the Interwar Arab East." International Journal of Middle East Studies 43,2 (May 1, 2011): 205-25.

Robson, Laura, ed. Minorities and the Modern Arab World. New Perspectives. New York: Syracuse University Press, 2016.

Rumelili, Bahar \& Fuat Keyman. "Enacting multi-layered citizenship: Turkey's Armenians' struggle for justice and equality," Citizenship Studies (2016): 20:1, 67-83.

Salomoni, Fabio. "Balkan Migrations to Modern Turkey: Continuity and Change." In The Borders of the Polity. Migration and Security across the EU and the Balkans, edited by Luisa Chiodi, 143-67. Ravenna: Longo, 2005.

Sepetçioğlu, Tuncay Ercan. "Girit'ten Anadolu'ya Gelen Göçmen Bir Topluluğun Etnotarihsel Analizi: Davutlar Örneği." Unpublished PhD, Ankara Üniversitesi, 2011.

Sinanoğlu, N.H. "Soyadı dolayında bir iki düşünce." Milliyet, 12 January 1933.

Spencer, Robert F. "The Social Context of Modern Turkish Names," Southwestern Journal of Anthropology 17,3 (1961): 205-218.

Suciyan, Talin. The Armenians in Modern Turkey. Post-Genocide Society, Politics and History. London: I.B. Tauris, 2016.

Szurek, Emmanuel. "To Call a Turk a Turk: Patronymic Nationalism in Turkey in the 1930s," Revue d'histoire moderne et contemporaine [Online] 6o,2 (2013).

T.C. Dahiliye Vekâleti. Nüfus İşleri Umum Müdürlügü Neşriyatı, Nüfus Kılavuzu. Hizmete Mahsus, Istanbul: Cumhuriyet Matbaası, 1938.

Türköz, Meltem. "Surname Narratives and the State-Society Boundary: Memories of Turkey's Family Name Law of 1934." Middle Eastern Studies 43,6 (2007): 893-9o8.

Türköz, Meltem. Naming and Nation-Building in Turkey. The 1934 Surname Law. New York: Palgrave Macmillan, 2018.

Ülker, Erol. "Assimilation, Security and Geographical Nationalization in Interwar Turkey: The Settlement Law of 1934." European Journal of Turkish Studies [Online], 7 (2008). 
Ulugöl, Mehmet Cem. “Osmanlı ve Türkiye'de Vatandaşlık Kavramı, Azınlıklar Üzerinde Etkisi ve Uygulamaları.” Unpublished Master's Thesis, İstanbul Bilgi Üniversitesi, 2009 .

Üngör, Uğur Ümit. The Making of Modern Turkey. Nation and State in Eastern Anatolia, 1913-1950. Oxford - New York: Oxford University Press, 2011.

Yeşiltuna, Serap. “1934 İskân Kanunu ve basındaki yansımaları.” Unpublished Master's Thesis, İstanbul Üniversitesi, 2006.

Yıldız, Ahmet. "Ne Mutlu Türküm Diyebilene." Türk Ulusal Kimliğinin Etno-Seküler Sınırları (1919-1938). Istanbul: İletişim, 2001.

Zürcher, Erik Jan. "Unionists and Kemalists: Refugees, Killers and Nation-builders." lecture given in Cetobac Seminar Series, Paris, 15 May 2017. 